DOI https://doi.org/10.32837/app.v0i65.310

УДК 321.7:316.628.157

\author{
Н. О. Стеблина \\ 0000-0001-9799-9786 \\ кандидат наук із соијальних комунікацій, \\ докторант каредри політології та державного управління \\ Донецького національного університету імені Василя Стуса
}

\title{
РЕПРЕЗЕНТАЦІЯ ПОЛІТИЧНИХ АКТОРІВ У ЦИФРОВОМУ ПОЛІТИЧНОМУ ДИСКУРСІ УКРАЇНИ У 2019 РОЦІ: ФОРМАЛЬНИЙ АНАЛІЗ
}

У цифрові часи теза К. Дойча про те, що політична система може бути окреслена через мережу комунікацій та інформаційних потоків стає все більш актуальною (Морозова, 2011, с. 104). Адже сьогодні враховувати потрібно не лише комунікацію й інформацію, яку обробляють та поширюють політичні актори (суб'єкти й інститути), але й різноманітні засоби інформації та цифрові майданчики (медіа) для комунікації, які постійно оновлюються. Водночас пам'ятаємо про спостереження М. Маклюена щодо «media», які формують «message». Отже, визначаємо нову - цифрову - логіку функціонування політичного дискурсу - у сучасній «гібридній медіасистемі» (Chadwick, 2013). Це передбачає як пряму (без участі засобів масової інформації (далі - 3МI), наприклад, через соцмережі, блоги, сайти й ін.), так і традиційну - опосередковану (з участю 3МI) взаємодію громадськості та політичних авторів. Водночас кількість інформації, що передається напряму, поступово збільшуватиметься, отже, концепція взаємозалежності 3МІ та політичних акторів для цифрового політичного дискурсу втрачатиме актуальність.

Нагадаємо, що саме концепцію взаємозалежності дослідники вважають оптимальною для демократичного суспільства, коли ЗМІ та політичні актори контролюють один одного: політичні актори «залежать від медіагромадськості, масмедіа залежать від політичної інформації» (Штромайєр, 2008, с. 122).

Проте за часів цифрового політичного дискурсу цей баланс порушується, оскільки політичні актори можуть обходитися без ЗМІ. Показовим у цьому плані може вважатися відомий твіт Д. Трампа «The Fake News Media hates when I use what has turned out to be my very powerful Social Media - over 100 million people! I can go around them» («Фейкові ЗМІ ненавидять, коли я використовую соціальні медіа, які виявилися дуже впливовими. Більше 100 мільйонів людей. І я можу звертатися до них»). А в українських реаліях - заява колишнього голови Офісу президента А. Богдана про те, що команді В. Зеленського «не потрібні журналісти для спілкування із журналістами» (Censor.net.ua, 2019).

Порушення цього балансу є також однією із причин «кризи демократії», за якої кардинально змінюється політична комунікація і нормою стають речі, які б за часів традиційної опосередкованої взаємодії між громадськістю і політичними акторами призвели до руйнації політичної репутації (Schneiker, 2019). Наприклад, цілком звичними в цифровому політичному дискурсі стають «імпульсивність, неввічливість, грубість <...> приниження інших» $(\mathrm{Ott}$, 2017, с. 64), негативізм, «атаки твітами» (Lee, Xu, 2018, с. 22), «поширюється мова ворожнечі», екстремізм та расизм (McGranahan, 2019, с. 3165), нівелюється об'єктивність та відповідальність (Pérez-Curiel, Naharro, 2019, с. 65).

Окрім політичної комунікації, зміни відбуваються й у тому, як у цифровому дискурсі репрезентуються політичні актори. Зокрема, відбувається маркетизація цифрового політичного дискурсу, за якої важливішою за зміст політичного повідомлення стає популярність політичного актора (Thompson, 2016; Schneiker, 2019), «сила привабити аудиторію» - важливішою за «силу комунікації» (Zhang et al., 2018), історія - важливішою за джерело інформації (Tari, Emamzadeh, 2018, с. 79). У цифровому політичному дискурсі ЗМІ стають білыш залежними від політичних акторів, просто передруковують їхні заяви (Blassnig et al., 2019; Ernst et al., 2019), водночас не відбувається процес журналістської медіації (López-Rabadán, Mellado, 2019, с. 3). 
Також незбалансованим за часів цифрового політичного дискурсу лишається склад політичних акторів, які репрезентуються у ЗМІ. Наприклад, згідно з дослідженням політичних блогів, у них найчастіше передаються мейнстрімні, а не альтернативні позиції (Kenix, 2009, c. 820). В інших мережевих форматах, зокрема в політичних новинах, участь громадськості мінімальна через низьку залученість до політичної комунікації, через падіння інтересу до неї, а також через зниження довіри до політичних інститутів.

За таких умов видається важливим з'ясувати, як саме політичні актори репрезентуються в цифровому політичному дискурсі, наскільки збалансована ця репрезентація, який склад найбільш популярних політичних акторів.

Для цього був здійснений формальний аналіз цифрового політичного дискурсу на матеріалі політичних новин незалежного українського видання «Українська правда» за 2019 р. Отримані результати зіставлялися з даними 2005, 2010 та 2015 рр.

Саме 2019 р. було обрано через інтенсивність політичних подій: президентські вибори, позачергові парламентські вибори, прихід на політичну арену нової політичної сили й ін.

Для формального аналізу цифрового політичного дискурсу використовувалося декілька показників:

Диверсифікація ЦПД - кількість згадок про політичних акторів у заголовках новин (рис. 1). Що більша присутність політичних акторів, то більша диверсифікація політичного дискурсу, зокрема, показник диферсифікації для повноцінного політичного діалогу теоретично має бути на рівні 2, де в політичному тексті згадується два і більше політичних акторів; таким чином відбувається політична взаємодія, обмін думками й ін. Згідно з попередніми дослідженнями, показник диверсифікації політичного дискурсу у 2005 р. становив 2,3, у 2010 р.- 1,6, у 2014 р.- 1,3.

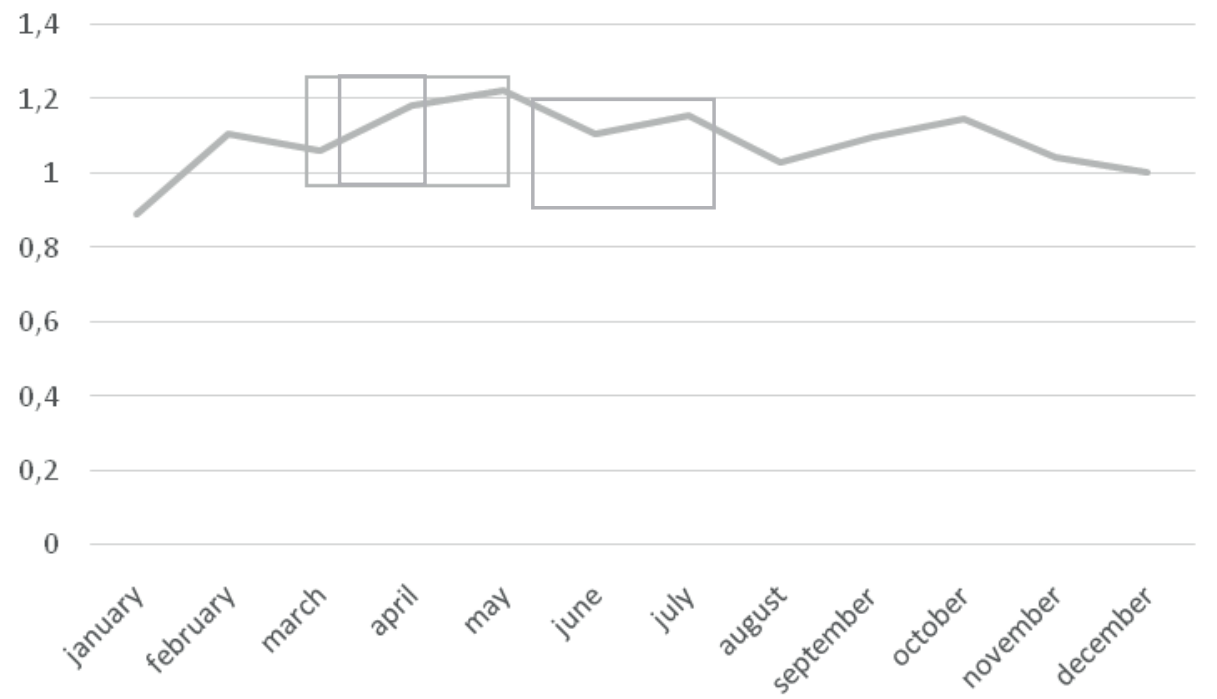

Рис. 1. Диверсифікація ЦПД. Середня кількість назв політичних суб'єктів та інститутів

Унікальність ЦПД - кількість унікальних згадок про політичних акторів у заголовках новин (рис. 2). Цей показник дає змогу зрозуміти, наскільки постійною є увага до тих або інших політичних суб'єктів та інститутів. Отже, чим більший показник унікальності, тим більше акторів постійно присутні у ЦПД (і розподіл згадок про них - більш рівномірний). Згідно з попередніми дослідженнями, показник унікальності спадав із 2005 та 2010 рр., коли він становив 31 та 29\%, у 2014 р. зріс - 53,3\%.

Збалансованість ЦПД - різниця між згадками про 1-2-у позиції у списку найбільш популярних політичних акторів (рис. 3). Вимірюючи цей показник, розуміємо, наскільки значним $\epsilon$ розрив між згадками про першу позицію у списку (як правило, президент країни) та згадками про другу позицію. Згідно з попередніми дослідженнями, у 2005 р. було зафіксовано 62 згадки про В. Ющенка і 46 про Ю. Тимошенко, отже, розрив між ними був незначним - 0,7. За часів В. Януковича показник знизився до 0,4 (100 згадок про В. Януковича та 41 про Ю. Тимошенко). У 2014 р. лишився приблизно на тому ж рівні - 0,38. 


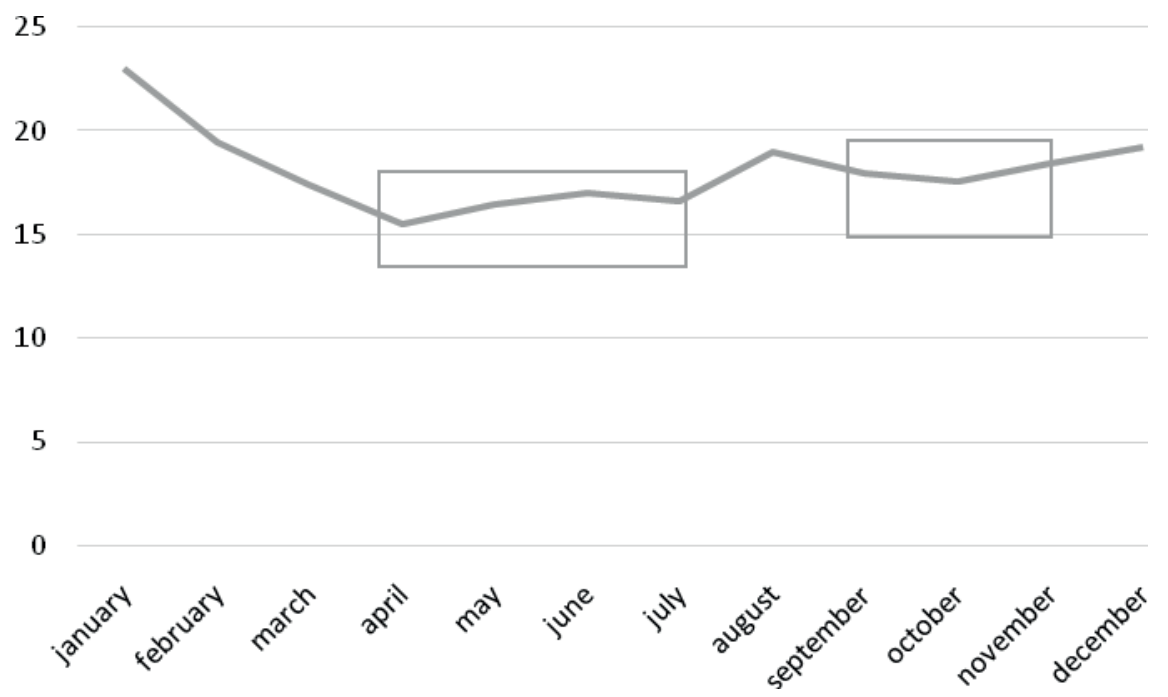

Рис. 2. Унікальність ЦПД. Кількість унікальних назв політичних суб'єктів та інститутів

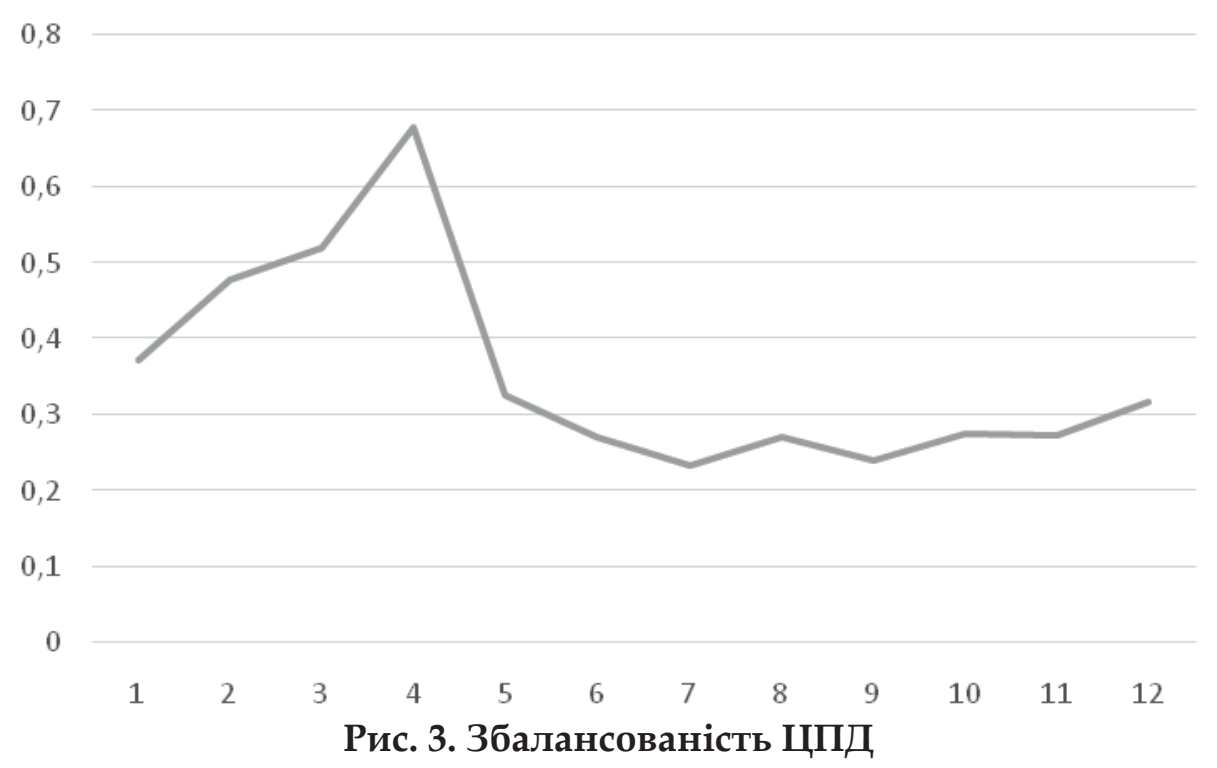

Отже, попередні спостереження дають змогу встановити декілька тенденцій: зниження показників диверсифікації та збалансованості політичного дискурсу та збільшення показника унікальності. Фактично, це має призводити до того, що ЦПД стає більш монологічним (кількість новин - збільшується, але присутність політичних акторів у них зменшується, через це політичні новини поступово втрачають значення майданчика для політичної взаємодії). Водночас відрив найбільш популярної позиції (президента) від інших позицій збільшується і цей діалог стає менш різноманітним за кількістю учасників. До того ж більшість політичних акторів - непостійні учасники цієї політичної взаємодії, що робить ЦПД більш епізодичним. Вимірявши ці показники у 2019 р., зможемо зрозуміти, чи вплинула на них зміна влади та значне оновлення складу політичних акторів, чи показники залишилися на тому ж рівні.

Інформацію збирали за допомогою програми find_political_actors.py, написаної мовою Python. Усього було оброблено більше 21 тис. заголовків новин сайту «Українська правда».

Середнє (медіана) за рік - 1,1 (тобто показник продовжує знижуватися порівняно 3 попередніми роками спостережень). Однак бачимо періоди більшої і меншої диверсифікації. У 2019 р. вони збігаються з передвиборчою кампанією та виборами.

Перший період (березень - травень). Президентські вибори призводять до найбільш тривалого періоду диверсифікації, водночас у травні зафіксовано найбільший показник за весь період спостережень - 1,22. Фактично - це результат публічного обговорення результатів виборів, зміни влади. 
Проте, як бачимо, зміна влади не приводить до змін у дискурсі за цим показником. Період обговорення результатів виборів закінчується травнем, потім диверсифікація спадає до середнього рівня.

Другий період (липень). Незначне зростання - теж збігається з виборами. Однак зазвичай парламентські вибори та й сама передвиборча кампанія не $є$ настільки ж обговорюваною подією, що й президентські вибори.

Третій період (вересень - жовтень). Це початок роботи нової Ради та нового уряду. А також публічне обговорення формули Штайнмаєра. Але знову ж таки період більшої диверсифікації - незначний. Уже в листопаді показник спадає до середнього рівня.

Середнє (медіана) за рік - 17,7\%. Це означає, що у 2019 р. увага була зосередженана на тих самих політичних акторах. І відсоток унікальних політичних суб'єктів та інститутів усе ж знижується із часом (за винятком 2014 р., що, ймовірно, можна пояснити початком російської агресії, а також появою в дискурсі нових осіб: військових, волонтерів, активістів та ін). Цікаво, що поява нових політичних акторів у 2019 р. не привела до зміни цього показника.

Оскільки між диверсифікацією й унікальністю ЦПД є негативна кореляція $(-0,8)$, то бачимо, що в періоди більшої диверсифікації дискурсу в ньому репрезентовані ті самі особи. I тут якраз зміна влади не підриває логіки цифрового політичного дискурсу. Тобто з'являються нові політичні суб'єкти й інститути, проте увага до них розподіляється так само, як і раніше.

Ось яку картину отримуємо, якщо визначаємо різницю між увагою до першої позиції в рейтингу згадуваності (П. Порошенко (до березня) - В. Зеленський (із квітня)) та до другої (В. Зеленський, Ю. Тимошенко, П. Порошенко, А. Богдан, П. Шеремет - детальніше в таблиці 1). До квітня є зниження відстані між № 1 та № 2, після цього зменшення та певна стабілізація уваги.

Отже, тенденція значного розриву між першим і другим найбільш популярними політиками зберігається, проте все ж потребує подальшого аналізу, оскільки дані за 2005, 2010, 2014 рр. збиралися лише за перші три місяці правління нового президента.

Таблиця 1

Рейтинг згадуваності політичних суб'єктів (топ-5 суб'єктів рейтингу щомісяця)

\begin{tabular}{|l|c|c|c|c|c|c|c|c|c|c|c|c|}
\hline & JAN & FEB & MAR & APR & MAY & JUN & JUL & AUG & SEP & OCT & NOV & DEC \\
\hline П. Порошенко & 70 & 109 & 156 & 229 & 109 & 73 & 60 & 53 & 32 & 43 & 43 & 35 \\
\hline А. Гриценко & 26 & & 44 & & & & & & & & & \\
\hline В. Зеленський & 26 & 31 & 81 & 338 & 335 & 269 & 257 & 195 & 250 & 221 & 157 & 183 \\
\hline П. Клімкін & 26 & & 30 & & 32 & 52 & 40 & & & & & \\
\hline Ю. Луценко & 17 & & 30 & & & & & 22 & & & 23 & \\
\hline Ю. Тимошенко & 17 & 52 & 76 & 21 & & & & & & & & \\
\hline К. Гандзюк & & 33 & & & & & & & & & & \\
\hline В. Янукович & & 32 & & & & & & & & & & \\
\hline І. Коломойський & & & 34 & 46 & & & & & & & & \\
\hline В. Медведчук & & & 18 & & 25 & & & & & & & \\
\hline С. Вакарчук & & & & & 54 & 50 & 44 & & & & & \\
\hline В. Гройсман & & & & 32 & & & & & & & & \\
\hline А. Богдан & & & & & & & 36 & 46 & 52 & 56 & & \\
\hline В. Кличко & & & & & & & & 19 & 34 & 20 & 28 & \\
\hline В. Гонтарева & & & & & & & & 28 & & & & \\
\hline О. Гончарук & & & & & & & & & & 21 & 20 & 18 \\
\hline О. Гладковський & & & & & & & & & 20 & & & \\
\hline П. Шеремет & & & & & & & & & & & & 58 \\
\hline А. Аваков & & & & & & & & & & & & 18 \\
\hline Р. Труба & & & & & & & & & & & & 18 \\
\hline
\end{tabular}


За рейтингом згадуваності фіксуємо, по-перше, чітку, без коливань зміну уваги до президента: у місяць переобрання (це може свідчити про харизматичний характер української політики, що стає ще більш виразним за часів цифровізації). По-друге, колишній президент лишається фігурою № 2 протягом чотирьох місяців і потім повертається в листопаді (імовірно, через розмови про «червоні лінії» - своєрідний розігрів перед зустріччю нормандської четвірки). По-третє, цікава позиція другої фігури - А. Богдан у вересні - жовтні - із подальшим падінням уваги до нього. I П. Шеремет (у зв' язку з оголошенням результатів «розслідування» його справи). Фактично, для дискурсу це може означати певний період невизначеності, коли за фігурою президента не стоять інші впливові фігури.

Висновки. Отже, формальний аналіз цифрового політичного дискурсу показав декілька тенденцій:

По-перше, зниження показника диверсифікації. Це означає, що в основному політичний текст містить згадку про одну особу, отже, із часом діалогічність дискурсу зменшується. Також бачимо, що в українських реаліях зміна влади не призвела до зміни рівня диверсифікації політики.

По-друге, збільшення показника унікальності. Окрім того, що в цифровому політичному дискурсі стає все менше діалогічності, взаємодія зводиться до тих самих акторів. Отже, «ієрархія доступу» (Atton, 2002), згідно з якою в дискурсі зосереджується увага на найбільш статусних, впливових, заможних політичних актантах, працює і за цифрових часів. I навіть посилюється. Наявний суттєвий дисбаланс між представленістю політичних актантів, отже, політичний дискурс держави неминуче стає викривленим. Актуальними лишаються також спостереження про інформаційну гегемонію (Лалл, 2002), за якої в політичному дискурсі держав, зокрема й демократичних, більше репрезентований офіційний порядок денний через зв'язок між офіційними політичними інститутами, великим бізнесом та масмедіа. А також працює «індексна теорія» (Bennet et al., 2008, с. 60), згідно з якою альтернативні позиції в офіційному політичному дискурсі представлені незначною мірою, а для того, щоб вони стали поміченими масмедіа, їх має оприлюднити джерело, що має вплив та статус.

По-третє, поступово зростає розрив між першою, найбільш впливовою та статусною позицією (зазвичай президент) та другою позицією в рейтингу згадуваності. За таких умов президент має певну монополію на присутність у дискурсі, а отже - на формування порядку денного.

Вимірювання цифрового політичного дискурсу за цими трьома показниками можемо вважати доцільним, щоб отримати більш повну картину політичного життя в Україні.

\section{Лimepamypa:}

Atton C. Alternative Media. London : Sage, 2002.

Bennet L., Lawrence R., Livingston S. When the press fails. Political power and the News Media from Iraq to Katrina. Chicago : the University of Chicago press, 2008.

Populism in Online Election Coverage / S. Blassnig et al. Journalism Studies. 2019. № 20 (8). P. 1110-1129. DOI:10.1080/1461670X.2018.1487802.

Broersma M., Graham T. Twitter as a news source: How Dutch and British newspapers used tweets in their news coverage, 2007-2011. Journalism Practice. 2013. № 7(4). P. 446-464. DOI:10.1080/17512786.2013.802481.

Нам не потрібні 3MI, щоб спілкуватися із суспільством, - Богдан. Censor.net.ua. 2019. URL: https://censor.net.ua/ua/news/3141117/nam_ne_potribni_zmi_schob_spilkuvatysya_iz_suspilstvom_ bogdan_video.

Favorable Opportunity Structures for Populist Communication: Comparing Different Types of Politicians and Issues in Social Media, Television and the Press / N. Ernst et al. The International Journal of Press/Politics. 2019. № 24(2). P. 165-188. DOI:10.1177/1940161218819430.

Heiss R., von Sikorski C., Matthes J. Populist Twitter Posts in News Stories: Statement Recognition and the Polarizing Effects on Candidate Evaluation and Anti-Immigrant Attitudes. Journalism Practice. 2019. № 13. P. 20-38. DOI: 10.1080/17512786.2018.1564883.

Kenix L. Blogs as Alternative. Journal of Computer-Mediated Communication. 2009. № 14. P. 790-822.

Lee J., Xu W. The more attacks, the more retweets: Trump's and Clinton's agenda setting on Twitter. Public Relations Review. 2018. № 44(2). P. 201-213. DOI: 10.1016/j.pubrev.2017.10.002.

López-Rabadán P., Mellado C. Twitter as a space for interaction in political journalism. Dynamics, consequences and proposal of interactivity scale for social media. Communication \& Society. 2019. № 32(1). P. 1-18. DOI: 10.15581/003.32.1.1-18. 
Matuszewski P., Szabó G. Are Echo Chambers Based on Partisanship? Twitter and Political Polarity in Poland and Hungary. Social Media + Society. 2019. DOI: 10.1177/2056305119837671.

McGranahan C. A Presidential Archive of Lies: Racism, Twitter, and a History of the Present. International Journal of Communication. 2019. № 13. P. 3164-3182.

Ott B. The age of Twitter: Donald J. Trump and the politics of debasement. Critical Studies in Media Communication. 2017. № 34(1). P. 59-68. DOI: 10.1080/15295036.2016.1266686.

Pain P., Chen G. The President Is in: Public Opinion and the Presidential Use of Twitter. Social Media + Society. 2019. DOI: $10.1177 / 2056305119855143$.

Park C., Kaye B. Expanding Visibility on Twitter: Author and Message Characteristics and Retweeting. Social Media + Society. 2019. DOI: 10.1177/2056305119834595.

Pérez-Curiel C., Naharro P. Political influencers. A study of Donald Trump's personal brand on Twitter and its impact on the media and users. Comunicacion y Sociedad. 2019. № 32(1). P. 57-76. DOI:10.15581/003.32.1.57-75. Schneiker A. Telling the Story of the Superhero and the Anti-Politician as President: Donald Trump's Branding on Twitter. Political Studies Review. 2019. № 17(3). P. 210-223. DOI: 10.1177/1478929918807712.

Tari Z., Emamzadeh Z. An Analysis of the Media Messages during the 2016 U.S. Presidential Election: A Thematic Comparison between CNN News and Donald Trump's Tweets. Journal of Politics and Law. 2018. № 11 (2). P. 78-87. DOI: 10.5539/jpl.v11n2p78.

Thompson M. Enough Said: What's Gone Wrong with the Language of Politics? New York : St. Martin's Press, 2016.

Whose Lives Matter? Mass Shootings and Social Media Discourses of Sympathy and Policy, 2012-2014 / Y. Zhang et al. Journal of Computer-Mediated Communication. 2019. № 24 (4). P. 182-202. DOI:10.1093/jcmc/ zmz009.

Attention and amplification in the hybrid media system: The composition and activity of Donald Trump's Twitter following during the 2016 presidential election / Y. Zhang et al. New Media \& Society. 2018. № 20(9). P. 3161-3182. DOI: 10.1177/1461444817744390.

Лалл Дж. Мас-медіа, комунікація, культура: Глобальний підхід. Київ : К.І.С., 2002.

Морозова О. Политико-коммуникационные процессы в политическом управлении. Вестник Московского государственного гуманитарного университета имени М.А. Шолохова. 2011. № 3. С. 104-108.

Штромайєр Г. Політика і мас-медіа. Київ : Вид. дім «Києво-Могилянська академія», 2008.

\section{References}

Atton, C. (2002). Alternative Media, London: Sage.

Bennet, L., Lawrence, R., \& Livingston S. (2008). When the press fails. Political power and the News Media from Iraq to Katrina. Chicago: the University of Chicago press.

Blassnig, S., Ernst, N., Buchel, F., Engesser, S., \& Esser, F. (2019). Populism in Online Election Coverage. Journalism Studies 20(8), 1110-1129. doi:10.1080/1461670X.2018.1487802

Broersma, M., \& Graham, T. S. (2013). Twitter as a news source: How Dutch and British newspapers used tweets in their news coverage, 2007-2011. Journalism Practice 7(4), 446-464. doi: 10.1080/17512786.2013.802481. Censor.net.ua (2019). Nam ne potribni ZMI, shhob spilkuvatisja iz suspil'stvom, - Bogdan. VIDEO [We don't need mass media to speak with society - Bogdan. Vieo] Retrieved from: https://censor.net.ua/ua/ news/3141117/nam_ne_potribni_zmi_schob_spilkuvatysya_iz_suspilstvom_bogdan_video.

Ernst, N., Esser, F., Blassnig, S., \& Engesser, S. (2019). Favorable Opportunity Structures for Populist Communication: Comparing Different Types of Politicians and Issues in Social Media, Television and the Press. The International Journal of Press/Politics. 24 (2), 165-188. doi: 10.1177/1940161218819430.

Heiss, R., von Sikorski , C., \& Matthes, J. (2019). Populist Twitter Posts in News Stories: Statement Recognition and the Polarizing Effects on Candidate Evaluation and Anti-Immigrant Attitudes. Journalism Practice. 13, 20-38. doi: $10.1080 / 17512786.2018 .1564883$.

Kenix L.J. (2009) Blogs as Alternative. Journal of Computer-Mediated Communication. 14, 790-822.

Lee, J., \& Xu, W.W. (June 2018 г.). The more attacks, the more retweets: Trump's and Clinton's agenda setting on Twitter. Public Relations Review. 44(2), 201-213. doi: 10.1016/j.pubrev.2017.10.002.

López-Rabadán, P., \& Mellado, C. (2019). Twitter as a space for interaction in political journalism. Dynamics, consequences and proposal of interactivity scale for social media. Communication \& Society. 32(1), 1-18. doi: 10.15581/003.32.1.1-18.

Matuszewski, P., \& Szabó, G. (2019). Are Echo Chambers Based on Partisanship? Twitter and Political Polarity in Poland and Hungary. Social Media + Society. doi: 10.1177/2056305119837671.

McGranahan, C. (2019). A Presidential Archive of Lies: Racism, Twitter, and a History of the Present. International Journal of Communication 13, 3164-3182. 
Ott, B.L. (2017). The age of Twitter: Donald J. Trump and the politics of debasement. Critical Studies in Media Communication. 34 (1), 59-68. doi: 10.1080/15295036.2016.1266686.

Pain, P., \& Chen, G. (2019). The President Is in: Public Opinion and the Presidential Use of Twitter. Social Media + Society. doi: 10.1177/2056305119855143.

Park, C.S., \& Kaye, B.K. (2019). Expanding Visibility on Twitter: Author and Message Characteristics and Retweeting. Social Media + Society. doi: 10.1177/2056305119834595.

Pérez-Curiel, C., \& Naharro, P.L. (2019). Political influencers. A study of Donald Trump's personal brand on Twitter and its impact on the media and users. Comunicacion y Sociedad. 32(1), 57-76. doi: 10.15581/ 003.32.1.57-75.

Schneiker, A. (2019). Telling the Story of the Superhero and the Anti-Politician as President: Donald Trump's Branding on Twitter. Political Studies Review. 17(3), 210-223. doi: 10.1177/1478929918807712.

Tari, Z.G., \& Emamzadeh, Z. (2018). An Analysis of the Media Messages during the 2016 U.S. Presidential Election: A Thematic Comparison between CNN News and Donald Trump's Tweets. Journal of Politics and Law. 11(2), 78-87. doi: 10.5539/jpl.v11n2p78.

Thompson, M. (2016). Enough Said: What's Gone Wrong with the Language of Politics? New York: St. Martin's Press.

Zhang, Y., Shah, D., Foley, J., Abhishek, A., Lukito, J., Suk, J., ... Garlough, C. (July 2019 г.). Whose Lives Matter? Mass Shootings and Social Media Discourses of Sympathy and Policy, 2012-2014. Journal of Computer-Mediated Communication. (24(4)), 182-202. doi: 10.1093/jcmc/zmz009.

Zhang, Y., Wells, C., Wang, S., \& Rohe, K. (2018). Attention and amplification in the hybrid media system: The composition and activity of Donald Trump's Twitter following during the 2016 presidential election. New Media \& Society. (20(9)), 3161-3182. doi: 10.1177/1461444817744390.

Lull J. (2002). Mas-media, komunikacija, kul'tura: Global'nij pidhid [Mass-media, communication, culture: Global approach]. Kyiv: K.I.C.

Morozova O.S. (2011). Politiko-kommunikacionnye processy v politicheskom upravlenii [Political and Communication processes in political management]. Vestnik MGGU imeni M.A. Sholohova. 3, 104-108.

Strohmeier, G. (2008). Politika i mas-media [Politics and Mass-Media]. Kyiv: Vyd. dim “Kyevo-Mogiljans'ka akademija".

\section{Анотація}

Стеблина Н. О. Репрезентація політичних акторів у цифровому політичному дискурсі України у 2019 році: формальний аналіз. - Стаття.

У статті здійснено формальний аналіз цифрового політичного дискурсу України за 2019 рік. Інформація збиралася за допомогою програми find_political_actors.py, написаної мовою Руthon. Усього було оброблено більше 21 тис. заголовків новин сайту «Українська правда». Формальний аналіз проводився за трьома показниками, як-от: диверсифікація, унікальність та збалансованість. Середній показник диверсифікації - 1,1, цей показник у 2019 році продовжує знижуватися порівняно 3 попередніми роками спостережень. Однак бачимо періоди більшої і меншої диверсифікації. У 2019 році вони збігаються з передвиборчою кампанією та виборами. Проте зміна влади не призводить до змін у дискурсі за цим показником. Середній показник унікальності - 17,7\%. У 2019 році увага була зосереджена на тих самих політичних акторах. І відсоток унікальних політичних суб'єктів та інститутів знижується із часом. Водночас поява нових політичних акторів у 2019 році не призвела до зміни цього показника. Між показником диверсифікації й унікальності є негативна кореляція $(-0,8)$. Отже, у періоди більшої диверсифікації дискурсу в ньому репрезентовані ті самі особи. Щодо збалансованості ЦПД, фіксуємо збільшення показника до 0,7, однак пізніше спостерігається зниження і стабілізація показника на рівні 0,25. За рейтингом згадуваності фіксуємо чітку, без коливань зміну уваги до президента в місяць переобрання, а також постійну зміну другої за популярністю позиції. Для дискурсу це може означати певний період невизначеності, коли за фігурою президента не стоять інші впливові постаті. Отримані результати означають, що в основному політичний текст містить згадку про одну особу, із часом діалогічність дискурсу зменшується. Окрім того, що в цифровому політичному дискурсі стає все менше діалогічності, взаємодія зводиться до тих самих акторів. Поступово зростає розрив між першою, найбільш впливовою та статусною позицією (зазвичай президент) та другою позицією в рейтингу згадуваності. За таких умов президент має певну монополію на присутність у дискурсі, а отже - на формування порядку денного.

Кюючві слова: цифровий політичний дискурс, політична комунікація, Україна, вибори, формальний аналіз. 


\section{Summary}

Steblyna N. O. Representation of political actors in Ukrainian digital political discourse in 2019: formal analysis. - Article.

Formal analysis of Ukrainian digital political discourse in 2019 is conducted in the paper. Information was collected with Python program find_political_actors.py. More than 21 thousand headlines from a site "Ukrayins'ka pravda" were processed. Formal analysis was conducted with three indicators: diversification, uniqueness, balance. Diversification (average) is 1,1 and the indicator has been decreasing since 2005. However periods of larger/lower diversification are observed. In 2019 the periods are coincide with the preelection campaign and the elections. And the change of political elites didn't cause change in the discourse. Uniqueness (average) is - 17,7\%. In 2019 the same political actors were in the spotlight. And, the percent of unique political subjects and institutions has been decreasing. Again, the emergence of new political actors didn't change the indicator. There is negative correlation between the two indicators $(-0,8)$. Thus, in the periods of large diversification the same figures are represented in the discourse. As for balance, the indicator in creased to 0,7 in April (presidential election), however, afterwards decreased and stabilized at the level 0,25. In the mentions rating clear change of attention to president (from Poroshenko to Zelensky) is fixed. However, the second position of the rating was changed constantly. It may be supposed, that the period of uncertainty was started, and there were no powerful figures except the president himself. The results of the research are as follows: a political text contain the one mention of one political actor, and the dialogue potential of the discourse has been decreasing. Moreover, the interrelations is concentrated around the same actors. And, the gap between the first, most powerful figure (president as a rule) and the second one in the mentions rating has been increasing. So, a president gets a monopoly of existence in the discourse, and therefore - forms the agenda.

Key words: digital political discourse, political communication, Ukraine, elections, formal analysis. 